\title{
On the Core Competence of Chinese Manufacturing Industry under the New Formats of "Internet Plus"-A Case Study on Furniture Industry
}

\author{
Renping Zhang, Junrong Liu \\ College of Economy and Management, Leshan Normal University, Sichuan, China \\ Email: 20044841@qq.com
}

Received 27 November 2015; accepted 26 December 2015; published 29 December 2015

Copyright (C 2015 by authors and Scientific Research Publishing Inc.

This work is licensed under the Creative Commons Attribution International License (CC BY). http://creativecommons.org/licenses/by/4.0/

\section{(c) (i) Open Access}

\begin{abstract}
Through factor analyses, the paper makes a performance evaluation on the listed companies in furniture industry, finds out the representative companies and then analyzes their business strategies and ways to improve their core competence, which can offer references for the construction of the core competence of manufacturing industry in the context of the "Internet Plus". The analyses reveal that the core competence of enterprises can be improved by innovating network promotion, making use of e-commerce and creating the flexible production line etc.
\end{abstract}

\section{Keywords}

Core Competence, Internet Plus, Factor Analysis, Manufacturing Industry, Furniture

\section{Introduction}

In January 2011, proposing the "Industrial 4.0”, Industry-Science Research Alliance (FU) believes that industrial 4.0 is the fourth industrial revolution based on the Cyber-Physical System (CPS) [1]. The concept was officially launched in 2013 by the German government who plans to finish the mass-production, to achieve the greatest degree of the automation, personalization, flexibility and self-optimization of production and to improve production efficiency and the new production mode of reducing costs during the 10 - 15 years, which aims to greatly improve the productivity and achieve a revolutionary goal by making full use of CPS.

The concept of Industrial Internet is introduced by the GE. GE chairman and CEO, Jeffrey R. Immelt said in his speech that Industrial Internet is a huge physical world. Consisting of machine, equipment, facilities and 
system network, it can combine connectivity, big data and digital analysis perfectly on a deeper level. Industrial Internet is a new industrial revolution and it focuses on big data and cloud computing.

Internet Plus is an innovative integration of the Internet and traditional industries through online platforms and IT technology. In March 2015, The "Internet Plus" action plan was unveiled in the government work report by Premier Li Keqiang. Li said that China will develop the "Internet Plus" action plan to integrate mobile Internet, cloud computing, big data and the Internet of Things with modern manufacturing, to encourage the healthy development of e-commerce, industrial networks, and Internet banking, and to help Internet companies increase their international presence. "Internet plus Manufacturing" is "Made in China 2025".

The essence of the three, Industrial 4.0, industrial Internet and "Made in China 2025", is intelligent manufacturing. Under the background of "Internet Plus", the research on the competitiveness of Chinese manufacturing industry will create a higher productivity and a sustainable development for Chinese economy.

\section{Theoretical Basis}

\subsection{Core Competence}

In 1990, Prahlad and Gary Hamel first proposed the concept of core competence in the core competence of enterprises [2]. Since then, many scholars at home and abroad have studied the meaning of the core competence of enterprises. Those scholars represented by Hamel \& Prahalad (1994), Coynel (1997), Coombas (1996) [3] believe that the core competence is made up of skills, knowledge, organizing and learning ability etc. Coyne, Hall and Clifford hold that the core competence is a combination of a series of deep rooted and mutual complementary skills and knowledge among a group or team. So, one or more core processes can be implemented at a world top level [4]; Domestic scholars, Guan Yixin (2000), Chen Qingtai (1999), Shi Dongming (2002), and Zhou Xing (1999) described the concept of core competence from the perspective of customer value, product, management, innovation, core value, enterprise culture and so on. And Zhang Jianmin believes that the core competence is the combination of a series of complementary knowledge and skills within the enterprise, and it can make one or more key industries of the enterprise achieve the industry's top level [5].

Research on the elements of core competence is also one of the hot spots. Wang Bingan (2000) divided the elements of core competence into hard and soft aspects, and respectively discussed it from the aspects of core products, core technology or skills and management. Guan Yixin (2000), starting with market prediction, human resources development, brand strategy and system innovation, studied the constitution of core competence of enterprises; Xu Zhengliang and Wang Lizheng (2003) reckon that core competence is energy source of the competitive advantage of enterprises organically composed by the power of enterprise culture, learning ability and innovation ability [6].

Cultivating the core competence of enterprises is the purpose of the study on core competence. Helleloid and Simonin (1994) proposed that organizing learning is the fundamental way to establish and improve the core competence, and to obtain sustainable competitive advantage [7]. Zhang Xinhua, Fan Xian (2002) and other scholars believe that fostering the core competence includes three paths: internal cultivation, external acquisitions and joint development [8].

Under the new formats of "Internet Plus", the cultivation of core competence of Chinese manufacturing industry should follow the principles of value, expansibility, uniqueness, dynamics, basics etc. and construct a core competence of enterprises with Chinese characteristics.

\subsection{Factor Analysis}

Here is an assumption that there are $n$ samples with each one $j$ observation variables, respectively represented by $X_{1}, X_{2}, \cdots, X_{j}$. There are $m$ non observable factors. They are $F_{1}, F_{2}, \cdots, F_{m}$, and then the factor analysis model is:

$$
\begin{gathered}
X_{1}=a_{11} F_{1}+a_{12} F_{2}+\cdots+a_{1 m} F_{m}+\varepsilon_{1} ; \\
X_{2}=a_{21} F_{1}+a_{22} F_{2}+\cdots+a_{2 m} F_{m}+\varepsilon_{2} ; \\
\vdots \\
X_{j}=a_{j 1} F_{1}+a_{j 2} F_{2}+\cdots+a_{j m} F_{m}+\varepsilon_{j} .
\end{gathered}
$$


In model, $m<j$.

$F=\left(F_{1}, F_{2}, \cdots, F_{m}\right)$ is non observable vector. $F$ is $X$ 's common factor. Mean vector $E(F)=0$, covariance matrix $\operatorname{cov}(F)=1$, and then vector components are independent with each other. $\varepsilon=\left(\varepsilon_{1}, \varepsilon_{2}, \cdots, \varepsilon_{j}\right)$ is a special factor, independent from $F$ and $E(\varepsilon)=0 . A=\left(a_{j m}\right), a_{j m}$ is the factor load, that is, the correlation coefficient between the $j$ index and the $M$ factor. The greater the load value is, the more closely is related.

Factor analysis method describes each variable observed originally through the sum of the linear function and special factor of factors of the least number. Meanwhile, by using this method, the numerical value of the evaluation index can be nondimensionalized to eliminate the difference between the number and the dimension of the variables, and to enhance the comparability of the index.

\section{Empirical Analyses}

\subsection{Status Quo Analysis of Furniture Manufacturing Industry}

1) The industry develops stably. In 2014, as the macroeconomic adjustment is basically in place, the operating quality of furniture industry is recovered comprehensively. The development speed varies in a reasonable range and the development trend remains stable.

2) Policy support provides policy reassurance. The policy orientation of People's livelihood projects, Newtype Urbanization and other policies has become increasingly clear. A series of policies guarantee a healthy and sustainable development for furniture industry, such as developing mixed ownership economy, establishing free trade area, expanding inland open border, support the development of the non-public sector of the economy, etc.

3) Industry competition intensifies and purchasing power is inclined to shift to those famous and good products. With the continuous improvement of urban and rural residents' income, "brand consumption concept" has been widely accepted. Consumers' loyalty and support on certain brands will become a magic weapon for furniture enterprises to win the market in the future.

4) Human resources reserves are at risk. With the continuous expansion of the scale of production management, industry competition is becoming increasingly fierce, and the enterprises' demand level of managers increases rapidly. If the enterprise's management capabilities and human resources reserves can't adapt to the new environment, some negative impacts will be inflicted on the enterprise.

5) The real estate market regulation is at risk. To further strengthen and improve the real estate market regulation, stabilize market expectations, and promote the steady and healthy development of the real estate market, our country has introduced restriction, limited credit, second-hand housing business tax, personal income tax and other macro-control policies, and strives to combat speculative real estate investment, and stabilize house prices. The government real estate macro-control policies talked above has brought the slowdown in the growth of commercial housing demand, while there is a correlation between the furniture industry, decoration industry and the real estate industry. If macroeconomic control causes the real estate market to slump continuously, the furniture industry will be affected and its business performance will suffer a negative impact.

6) The consumption habits of emerging consumer groups have changed. The rise of Online to Offline has changed consumer interaction, which poses a certain impact on the traditional offline sales channels in custom industries. The ultimate direction of internet development is the service and the transparency of price information. For the custom industry enterprises, it is both an opportunity and a challenge.

7) Home industry is intelligentialized. With the improvement of living standard, consumers' desire of an intelligent, convenient, comfortable, customized living environment is increasingly strong and the concept of smart home is gradually popular. Smart home has a profound influence on the traditional concept of home life. As an emerging market, smart home industry enjoys a broad prospect in China and even in the world, and a huge market potential.

8) Marketing channels are diversified and electricity suppliers are still popular. With the intensification of market competition in the furniture industry and the refinement of positioning of the target consumer groups, China's furniture marketing mode is no longer confined in store display sales. The sudden emergence of channels of distribution can meet the needs of different levels of consumption and consumption habits. They include furniture stores, comprehensive furniture shops, and sales network and so on. Diversified pattern is beginning to take shape.

At present, the traditional store sales is still the mainstream of marketing channels, but what is particularly needed to be pointed out is that since 2011, the furniture business has been in a rapid development period. Do- 
mestic well-known furniture companies all begin to build the electronic business channels. E-commerce, online and offline sales and pure online sales have gradually prevailed among businesses and consumers, becoming a fashionable consumption patterns. During the " 11.11 " shopping carnival, many home furnishing brands that participate in the online sales has an outstanding performance. In 2015, it is expected that the furniture e-commerce will remain developing rapidly.

\subsection{Performance Evaluation on the Listed Corporation in Furniture Industry}

1) Establishment of Indication System

IS of performance evaluation on furniture industry is designed according to the 6 dimensions: enterprise profitability, debt paying ability, operating ability, growth ability, innovation ability and human resources. Following the principle of data availability and comparability, it selected 19 evaluation indexes, which is in Table 1.

2) Testing validity of the data

In this paper, we select 12 furniture listing companies. Based on 2014 annual report data, we use SPSS17.0 to analyze. The result is that KMO is 0.85 , which shows that variables are highly related; the Bartlett test results show that chi-square value is 220 and significance probability is 0.000 . Therefore, the null hypothesis of Bartlett, the KMO and Bartlett results show that the data is suitable for factor analysis.

3) Determining the factor load and naming the factors

According to the principle that the principal component Eigenvalues is greater than 1, we select 4 main factors. The Accumulated Variance Contribution Rate of these 4 factors is $91.29 \%$, which is useful to explain the original variable. Table 2 lists the Factor Eigenvalues, Variance Contribution Rate and Accumulated Variance Contribution Rate that meet the conditions of conditional factor after rotation.

Table 1. IS of performance evaluation on furniture industry.

\begin{tabular}{|c|c|c|}
\hline Evaluation elements & Evaluation indicator & Variable \\
\hline \multirow{3}{*}{ Profitability } & Return on assets (ROA) & $X_{1}$ \\
\hline & Rate of return on common stockholders' equity (ROE) & $X_{2}$ \\
\hline & Profit rate to net worth & $X_{3}$ \\
\hline \multirow{5}{*}{ Debt paying ability } & Current ratio & $X_{4}$ \\
\hline & Quick ratio & $X_{5}$ \\
\hline & Equity ratio & $X_{6}$ \\
\hline & Debt to tangible assets ratio & $X_{7}$ \\
\hline & Equity multiplier (EM) & $X_{8}$ \\
\hline \multirow{3}{*}{ Operating ability } & Total asset turnover ratio (TATO) & $X_{9}$ \\
\hline & Receivables turnover ratio & $X_{10}$ \\
\hline & Stockholder's equity ratio & $X_{11}$ \\
\hline \multirow{4}{*}{ Growth ability } & Earning per share (MPS) & $X_{12}$ \\
\hline & Operating income growth rate & $X_{13}$ \\
\hline & Total profit growth rate & $X_{14}$ \\
\hline & Net profit growth rate & $X_{15}$ \\
\hline \multirow{2}{*}{ Innovation ability } & Proportion of development and research expenses & $X_{16}$ \\
\hline & Proportion of technical personnel & $X_{17}$ \\
\hline \multirow{2}{*}{ Human resources } & Efficiency of labor & $X_{18}$ \\
\hline & The proportion of highly educated personnel & $X_{19}$ \\
\hline
\end{tabular}

Table 2. Factor eigenvalues, variance contribution rate and accumulated variance contribution rate.

\begin{tabular}{ccccc}
\hline & Factor $F_{1}$ & Factor $F_{2}$ & Factor $F_{3}$ & Factor $F_{4}$ \\
\hline Eigenvalues & 9.77 & 3.30 & 2.89 & 1.38 \\
Variance contribution rate & $51.41 \%$ & $17.39 \%$ & $15.21 \%$ & $7.28 \%$ \\
Accumulated variance contribution rate & $51.41 \%$ & $68.80 \%$ & $84.01 \%$ & $91.29 \%$ \\
\hline
\end{tabular}


The indicators load value of $F_{1}$ is more than $68 \%$ in Stockholder's equity ratio $\left(X_{11}\right)$, Current Ratio $\left(X_{4}\right)$, Quick Ratio $\left(X_{5}\right) . F_{1}$ is named "debt paying ability factor"; the indicators load value of $F_{2}$ is more than $67 \%$ in Proportion of technical personnel $\left(X_{17}\right)$, Proportion of development and research expenses $\left(X_{16}\right)$, the Proportion of highly educated personnel $\left(X_{19}\right)$, Profit rate to net Worth $\left(X_{3}\right)$, Return On Assets $\left(X_{1}\right) . F_{2}$ is named "innovation and profitability factor"; the indicators load value of $\mathrm{F}_{3}$ is more than $70 \%$ in Efficiency of labor $\left(X_{18}\right)$, Total Asset Turnover Ratio $\left(X_{9}\right)$, Rate of Return on Common Stockholders' Equity $\left(X_{2}\right)$, Receivables Turnover Ratio $\left(X_{10}\right) . F_{3}$ is named "operating ability factor". The indicators load value of $F_{4}$ is more than $68 \%$ in Total profit growth rate $\left(X_{14}\right)$, Net profit growth rate $\left(X_{15}\right)$, Earning Per Share $\left(X_{12}\right) . F_{4}$ is named "growth ability factor".

4) The score of main factors and comprehensive evaluation

Regression estimation, Bartlett, and Thomson estimation method are used to calculate the factor score. The variance contribution rate of each factor is the weight, and we get a comprehensive evaluation index function by a linear combination of each factor. $F=\left(w_{1} F_{1}+w_{2} F_{2}+\cdots+w_{m} F_{m}\right) /\left(w_{1}+w_{2}+\cdots+w_{m}\right) . W_{i}$ here is the variance contribution rate before or after rotation. The enterprise's comprehensive ranking is based on its comprehensive score. The results are shown in Table 3.

The results show that we should improve the performance of furniture enterprises by focusing on the following 4 elements: first, make bold innovation, and improve profitability. Dalian Kemian Wood Industry Co., Ltd. ranks first, and it makes the largest contribution to innovation and profit performance. As we can see, the company focused on cultivating high-quality and innovative talents, and actively develop new products, which influences the corporate's profitability and improvement of overall performance greatly. And so do Dare Technologies Global Co., Ltd. and Xi LinMen Furniture Co., Ltd. Second, improve the financial situation and solvency. Qu Mei Furniture Group Co., Ltd., Der International Home Furnishing Co., Ltd. and Suofeiya Home Collection Co. Ltd has prominent solvency and their comprehensive performances rank in the forefront, while Dare Technologies Global Co., Ltd. ranks last because of the weakest solvency. It suggests that Good financial situation and strong solvency play an essential role in improving the competitiveness of enterprises. Third, accelerate the flow of capital operations, and enhance the operational capacity. Those companies like Homelike,

Table 3. The main factor score and the overall ranking of 12 furniture listed companies.

\begin{tabular}{|c|c|c|c|c|c|c|c|c|c|c|}
\hline \multirow{2}{*}{ Company name } & \multicolumn{2}{|c|}{$F_{1}$} & \multicolumn{2}{|c|}{$F_{2}$} & \multicolumn{2}{|c|}{$F_{3}$} & \multicolumn{2}{|c|}{$F_{4}$} & \multirow{2}{*}{$\begin{array}{l}\text { Comprehensive } \\
\text { score }\end{array}$} & \multirow{2}{*}{ Ranking } \\
\hline & Score & Ranking & Score & Ranking & Score & Ranking & Score & Ranking & & \\
\hline $\begin{array}{l}\text { Markor International } \\
\text { Furniture Co., Ltd. }\end{array}$ & 0.104 & 5 & -0.590 & 10 & -0.423 & 8 & 0.809 & 3 & -0.054 & 6 \\
\hline $\begin{array}{l}\text { Suofeiya Home } \\
\text { Collection Co., Ltd }\end{array}$ & 0.868 & 3 & -0.100 & 5 & 0.296 & 2 & 0.036 & 7 & 0.047 & 3 \\
\hline $\begin{array}{l}\text { XiLin Men Furniture } \\
\text { Co., Ltd. }\end{array}$ & 0.010 & 6 & 0.228 & 3 & 0.081 & 3 & -2.651 & 12 & -0.136 & 7 \\
\hline Yotrio Group Co., Ltd. & -0.313 & 9 & -0.375 & 7 & -0.198 & 6 & 0.078 & 6 & -0.250 & 9 \\
\hline $\begin{array}{l}\text { Dare Technologies } \\
\text { Global Co., Ltd. }\end{array}$ & -2.428 & 12 & 0.506 & 2 & 0.039 & 5 & 0.032 & 8 & -1.152 & 12 \\
\hline $\begin{array}{l}\text { Der International Home } \\
\text { Furnishing Co., Ltd. }\end{array}$ & 1.086 & 2 & -0.430 & 8 & -0.338 & 7 & 0.937 & 2 & 0.500 & 2 \\
\hline Home Like & -0.023 & 7 & -0.558 & 9 & 2.994 & 1 & 0.296 & 5 & 0.368 & 5 \\
\hline $\begin{array}{l}\text { Guangdong Weihua } \\
\text { Corporation }\end{array}$ & -0.387 & 10 & -0.848 & 12 & -0.699 & 12 & 1.004 & 1 & 0.380 & 10 \\
\hline Shengda Forestry & -0.717 & 11 & -0.229 & 6 & -0.648 & 10 & -0.237 & 10 & 0.524 & 11 \\
\hline $\begin{array}{l}\text { Dalian Kemian Wood } \\
\text { Industry Co., Ltd. }\end{array}$ & 0.722 & 4 & 2.917 & 1 & 0.067 & 4 & 0.643 & 4 & 0.935 & 1 \\
\hline $\begin{array}{l}\text { Guangdong Yihua } \\
\text { Timber Industry Co., Ltd }\end{array}$ & -0.266 & 8 & 0.116 & 4 & -0.648 & 10 & -0.016 & 9 & -0.216 & 8 \\
\hline $\begin{array}{l}\text { Qu Mei Furniture } \\
\text { Group Co., Ltd. }\end{array}$ & 1.344 & 1 & -0.637 & 11 & -0.522 & 9 & -0.930 & 11 & 0.433 & 4 \\
\hline
\end{tabular}


Suofeiya Home Collection Co. Ltd, Xi LinMen Furniture Co., Ltd., has a high capital turnover rate and a better operating performance, making their comprehensive performance are among the top three. Fourth, improve the growth ability and accelerate the development. Guangdong Weihua Corporation, Der International Home Furnishing Co., Ltd, and Markor International Furniture Co., Ltd. all do better in Growth performance. And their comprehensive rankings are in front. But Guangdong Weihua Corporation ranks poorly because of its poor grow performance.

\section{Conclusions}

Through factor analysis, we can see that improving the performance of furniture enterprises should focus on improving its profitability, and the improvement of profitability relies on the cultivation of core competence. In the context of "Internet Plus", there will be more space for improving the enterprise's core competence. Following is the analysis of business strategy and core competence of some representative enterprises in performance, such as Qu Mei Furniture Group Co., Ltd., Dalian Kemian Wood Industry Co., Ltd. and Xi LinMen Furniture Co., Ltd. The purpose is to provide a reference to improve the core competence of Chinese manufacturing industry under the new formats of "Internet Plus".

\subsection{Innovating Network Promotion Way and Enhance Brand Advantage}

Network promotion is different from the traditional way of brand promotion. Enterprises can display their own brand image and undertake a full range of network brand popularizing through text, sound, pictures and animation, etc. [9].

1) Optimizing the official website construction. The official website is the preferred platform for enterprises to use network to carry on the image propaganda and the brand construction. Manufacturing industry can optimize the official website and unify visual image; optimize the product display on website, heighten the user's experience and raise the reputation of the products; design a page display form adapting mobile terminal and improve the image of the product.

2) Establishing user data. Create an exclusive electronic archive for every user. With the respect and protection of users' privacy, make a continuous analysis of users, provide personalized service experience, and increase customer loyalty.

3) Improving the reservation system. Set up a set of standard customer diversion mechanism from online to offline so that customer service can step in user consultation, booking, ordering and any other links, constantly optimize the service experience and improve brand loyalty and customer loyalty.

4) Social media and interactive marketing. Social media is an internet platform on which individuals communicate with each other through the registration, publishing, sharing, evaluation, discussion and other ways and its biggest feature is timeliness and interactivity. Add social and sharing function of the website. Form a user circle by scanning the product's QR code, using the function of WeChat, micro blog and QQ sharing together with making use of social media. And then aggregate the same user, share the product, frequently interact with customers so that a fans groups of the enterprises can be built up. It can utilize the fans economy to enhance brand awareness and acceptance.

\subsection{Make Use of E-Commerce and Accelerate the Product Research and Development}

Under the new formats of "Internet Plus", the traditional manufacturing industry should center on customer demand, build an e-commerce platform, focus on the following function constructions, and develop products meeting customer's demand.

1) To enhance the full-on customer experience. Integrate the Internet cloud platform with offline experience channel of the store. Realize the three screen linkage from PC, Tablet PC to mobile phone. Based on big data, provide customers with a targeted solution; Create colorful ways to experience, and ultimately achieve a full range of consumer experience through the electronic commerce platform.

2) Designing by customer, which means Expanding product design to design services. Professional designers provide online services to meet customer's demand for self-design and self-experience.

3) Intelligent production. Collect customer and product's data and research and analyze it to achieve a trinity mode of production: informational, personalized, and intelligent. 


\subsection{Create a Flexible Production System to Achieve Intelligent Production}

1) Optimizing equipment and upgrading process. Comprehensively optimizing the production line of manufacturing industry and increasing investment on production line of highly automated and intelligent products contribute to expand the production capacity of enterprises and enhance profitability; improving production process continuously helps to increase the production efficiency, improve the stability of production, raise the equipment operation rate, reduce consumption of products, improve the utilization of waste materials; Reasonably control energy consumption like water and electricity to produce environmentally.

2) Optimizing and restructuring the process. Optimize process restructure, business process design, equipment matching, and production balance which are based on internet production. Establish intelligent production modules, improve production capacity, and meet the needs of e-commerce operations.

\subsection{Opening up the Network Sales Channels and Improve Profitability}

1) Building official website. Set up an "exclusive shop" in the official website so that customers can order products in that page. At the same time, convenience of online shopping should be reflected in the search, browse, interaction, payment and other aspects.

2) Making use of electricity distribution platform like Taobao. E-commerce platform is where online transactions negotiation is offered for enterprises and individuals. By making full use of network infrastructure, payment platform, security platform, management platform and other shared resources provided by e-commerce platform, the enterprise can develop its business activities effectively and cheaply. Settle on the electricity distribution platform, and make use of its widespread influence to promote products and enlarge sales.

\subsection{Improving the Comprehensive Management Level and Ensure the Operation of the New System}

1) Introducing and fostering capable persons in e-business. The cultivation of e-commerce personnel is very necessary for the traditional manufacturing industry to turn into the "internet plus manufacturing". But e-business is a new industry. The talents shortage is also increasing. Therefore, Introducing and cultivating e-commerce talents is the foundation of transformation and development. These talents include website administrator, online customer service, website designers, Java engineers, etc.

2) Improving the organization and strengthening the internal control management. In order to implement the "Internet Plus" strategy successfully, the manufacturing industry should improve and perfect the organizational structure, strengthen internal control management, control the risk of enterprise's decision-making, improve the ability of merger and acquisition, and improve the overall level of business management.

\section{Acknowledgements}

The fund project, co-sponsored by Sichuan Federation of Social Sciences Circle and Leshan Normal University. Named "An analysis on achievement evaluation system of enterprise strategy management” (SC14XK12).

\section{References}

[1] Yang, S. (2015) Industrial 4.0 and Industrial Internet: Comparison, Revelation and Strategies. Contemporary Finance, 8, 99-107. http://www.cnki.net/kcms/doi/10.13676/j.cnki.cn36-1030/f.2015.08.010.html

[2] Prahalad, C.K. and Gary, H. (1990) The Core Competence of the Corporation. Harvard Business Review, 68, 79-91.

[3] Coombs, R. (1996) Core Competencies and the Strategic Management of R\&D. R\&D Management, 26, 345-355. http://dx.doi.org/10.1111/j.1467-9310.1996.tb00970.x

[4] Coyne, K.P., Hall, S.J.D. and Clifford, P.G. (2001) The Core Competitiveness. China Entrepreneur, 2, 86-89.

[5] Zhang, J.M. (2011) Rethinking on Core Competence. Technology Economy and Management, 1, 55-59.

[6] Xu, Z.L. and Wang, L.Z. (2003) A Discussion on the Original of Corporation Competitive Advantages; a Redefinition of the Corporation Core Competence. Jilin University Journal Social Sciences Edition, 9, 99-106. http://www.cnki.net/kcms/doi/10.15939/j.jujsse.2003.05.015.html

[7] Helleloid, D. and Simonin, B. (1994) Organizational Learning and a Firm’s Core Competence. Competence-Based Competition, 213-239. 
[8] Zhang, X.H. and Fan, X. (2002) Identification, Formation and Maintaining of Core Competitiveness of an Enterprise. Fudan Journal (Social Sciences), 5, 106-111.

[9] Chen, J.L. (2015) Network Promotion of National Brand-Taking Meizu, MI and Smartism as Research Object. Journalistic Sphere, 2, 217-218. http://dx.doi.org/10.1016/j.chemosphere.2014.11.040 